\title{
A Comparative Clinical Study of Jaladhara and Taildhara in the Management of Stress
}

\section{Research article}

\section{Neha G Tank ${ }^{1 *}$}

1. Reader, Shree Gulabkunverba Ayurved Mahavidyalaya, Gujarat Ayurved University, Jamnagar. 09825391284 email:nehajayraj@gmail.com

\begin{abstract}
In the present Era, stress is said to be one of the largest killers of man today. Stress is related to our total health - physical, mental and emotional. In Ayurveda stress is a resultant condition due to pragyaparadha. In the present study total 137 patients were registered and randomly divided into 3 groups viz: Group A were subjected to Jaladhara 7days along with Mansyadi Kwatha for 30days; Group B were subjected to Tailadhara for 7 days along with Mansyadi Kwatha for 30days; Group C received only Mansyadi Kwatha for 30days. The main aims \& object of the study are: 1) To study the comparative effect of Jaladhara and Tailadhara in the management of stress. 2) To study the clinical efficacy of Shirodhara. Assessment of the effect of treatment was done on the basis of relief in the subjective \& objective signs \& symptoms of stress and on Brief psychiatric rating scale. The data were analysed statistically. It was observed that symptoms like insomnia, anxiety etc were almost completely relieved in Shirodhara group. In Breif Psychiatric rating scale statistically results of both the dhara group are highly significant. Taildhara provided better relief in all most all the symptoms of Stress and in Brief psychiatric rating scale compared to Jaladhara.
\end{abstract}

Key Words: Jaladhara, Taildhara, Stress, Bio humors, Pragyapradha, Shirodhara

\section{Introduction:}

According to the American academy of family physicians, the majority of all physician visits are prompted by stress-related symptoms that are known to cause or worsen medical conditions.

The modern jet-age world, which is said to be a world of amazing achievements, is also a horrible world of stress. We find stress everywhere, whether it be within the family, business

*Corresponding Author:

\section{Neha G Tank}

Reader,

Shree Gulabkunverba Ayurved

Mahavidyalaya,

Gujarat Ayurved University, Jamnagar.

Mobile No: 09825391284

Email: nehajayraj@gmail.com organization, enterprise or any other social or economic activity. Right from the time of birth till the last breath drawn; an individual is invariably exposed to various stressful situations. Thus, it is not surprising that interest in the issue has been raising in the present century which can be appropriately called the "Era of Anxiety and stress" According to latest health reports, stress is said to be one of the largest killers of man today. Stress is now becoming more accepted as being crucially related to our total health physical, mental and emotional.

\section{Definition of stress:}

The term "stress" is difficult to define and may mean different things to different people in divergent circumstances. The oldest definition is that 
of Hans Selye who defined stress as the "non-specific (i.e. common) result of any demand on the body, whether the effect be mental or somatic".

Regarding 'stress', there is no direct reference available in Ayurveda texts. In various available dictionaries, meaning of stress words are- Aayaas, Pratyabala, Bhaar, Prayatna, Tanaav, etc.

(1) Hence it is clear that only terminological clarification is available to some extent but not detailed description regarding stress. So a hypothesis can be formulated where stress is correlated with Buddhi, Dhruti and Smriti Vibhramsha, which ultimately leads to Pragnaparadha. Pragnaparadha is mentioned as one of the causative factor for nearly all the diseases, especially mental diseases. Due to Pragnaparadha, a person is not able to perform his intellectual functions at its optimum level and fails to discriminate between right and wrong which results in numerous mental diseases. Stress is outcome of such conditions.

Approach of Ayurveda towards mental diseases always keeps uniqueness, as it does with all other diseases. In any disease changes in the basic constitution of the body, which are evolved from causes related to physical and mental functions, frame a morbid physiology. The routes of the diseases get embedded in the two inseparable aspects of the living being, the body and mind in varying proportions. It is the keynote for the mutual dependence of mind and body, through which Ayurveda developed its therapeutic basis.

The route cause of all these is, vitiation of bodily humors - Vaata, Pitta, and Kapha. Bodily humors though made of 5 elements are related with mind also. The normal physiological functions of the bodily humors include many psychological functions. Thus Vaata is responsible for enthusiasm, Pitta is responsible for the activities of brain and generation of intelligence and Kapha is responsible for intelligence and will power etc.(2) of the three humors, Vaata is mainly responsible for the activities of the mind. It is controller and stimulator of mind.(3) (4) Coming to the divisions of Vaata, we find Prana is the supporter of the mental functions and Udana is responsible for the generation of memory (5) and amongst the types of Pitta, Sadhaka Pitta is directly related to the functions of mind.(6)

Changes in bodily humors affect the mind too. Vitiated bodily humors adversely effect the normal functioning of mind. Taking into consideration the above factors of Vaata, it is evident that Vaata is of prime important among humors. This is true in the case of mental disorders also. Shirodhara is one of the treatment which helps to control the function of mind and is therefore selected for the present study of stress where mind is mainly vitiated. Shirodhara is described under Murdha Tail.

Murdha Tail - Shirahatarpana is suggested treatment for any disorders occurring in head region.(7) Vaghbhatta has divided Murdha Tail into 4 divisions and suggested as "Uttarotara" Gunaprada i.e., Sequentially more beneficial; they are 1) Shiro - Abhayanga(2) Shira - Seka (3) Shira - Pichudharana (4) Shiro - Basti.

According to classics Shirodhara should be done with Sneha only as it falls under Murdha Tail but, as the medicated oils are very costly and whole society cannot consummate it for the treatment Jaladhara came into existence.

Many research works are carried out on Jaladhara and Tailadhara individually but very few research works are carried out for any comparative assessment of Dhara.

Mansyadi Kwatha is given as a follow up drug after Shirodhara as stress is a psychic disease which requires some drug treatment (internal) also. Mansyadi Kwatha is widely utilized in GAU Jamnagar for many psychic diseases, as it contains, Ashwagandha (Withania Somnifera), Jatamansi (Nordostachys 
Jatamansi) and Khurasani Ajowain (Hyoscyamus Niger). It is a reference of Siddha Yoga Samgraha and is indicated for Apasmara (Epilepsy) \& Akshepa (Convulsions) etc psychic conditions.

\section{Importance of present study:}

Stress being a crucial problem world wide, various psychiatric medicines have come in to existence for its cure. But it leads to drug addiction, drug dependency and many physical and mental side effects. Such patients are always in search of better treatment with least side effects. Shirodhara is a treatment with better results and has no side effects at all. It is only external treatment. Shirodhara is described under Snehana treatment, but in the present world various drugs like decoction, water, butter milk etc are utilized for Shirodhara. So, here an effort is done to find out the comparative effect of Jaladhara and Taildhara in the management of stress. There is always question for drug absorption through Shirodhara which is tried to explain to some extent.

\section{Aims and objects:}

1) To study the comparative effect of Jaladhara and Tailadhara in the management of stress.

2) To study the clinical efficacy of Shirodhara

3) To study the clinical efficacy of Mansyadi Kwatha in the management of stress.

\section{Material and method: \\ Clinical study:}

To evaluate the therapeutic effect of Shirodhara clinical study was undertaken.

\section{Criteria of selection:}

Patients with signs \& symptoms of stress attending I.P.G.T.\& R.A. hospital O.P.D \& I.P.D. were selected irrespective of age, sex, occupation, religion, financial status etc.

\section{Criteria of exclusion}

Patients presenting with severe complications like schizophrenia, insane etc were not taken for the study.

\section{Investigations}

All the patients selected were subjected to routine investigations to rule out any complications.

(1) Blood investigations: $\mathrm{Hb}, \mathrm{TC}, \mathrm{DC}$, ESR, and PCV etc.

(2) Urine investigations: routine \& microscopic examination.

(3) Stool investigations: routine \& microscopic examination.

(4) Biochemical examination.

\section{Grouping:}

The selected patients were randomly placed \& studied under three groups.

- Group A were subjected to Jaladhara along with Mansyadi Kwatha.

- Group B were subjected to Tailadhara along with Mansyadi Kwatha.

- Group C (standard control group) received Mansyadi Kwatha

\section{Drug, Dose \& Duration \\ Drugs:}

- Internal drug:-Mansyadi Kwatha

- External drugs: For Shirodhara-water and sesame oil.

Dose:

- Mansyadi Kwatha 20 Ml B.D.

- Approximately 3 liters water/ sesame oil for Shirodhara.

\section{Duration:}

The Duration was 7 Days for Shirodhara followed by Mansyadi Kwatha for 30 days in group A group B. In group C only mansyadi kwatha was given for 30 days. 
Follow up study: ONE-MONTH follow up study.

\section{Ahara \& Vihara:}

Patients under study were advised about Ahara \& Vihara as indicated in the management of Vaata Vriddhi.

\section{Criteria of Assessment:}

Assessment of the effect of treatment was done on the basis of the relief in the subjective \& objective signs \& symptoms of stress. The data were analysed statistically.

\section{Brief Psychiatry Rating Scale:}

Signs and symptoms mentioned in this scale were assessed by adopting the following scoring pattern.

Gradation for each symptom:

ABSENT-0/MILD-1/MODERATE2/SEVERE-3

The available adopted score is grouped and scored as follows:

$$
\begin{array}{ll}
0-3 & + \\
4-6 & ++
\end{array}
$$

$$
7-9+++
$$

\section{Overall Effect of Therapy}

Overall effect of the therapy was assessed in terms of complete remission, marked improvement, moderate improvement, improvement and unchanged by adopted the following criteria.

- Complete remission: $100 \%$ relief in the Brief Psychiatry Rating scale was considered as complete remission.

- Marked improvement: $75 \%$ to $99 \%$ relief in the score of the Brief Psychiatry Rating scale was taken as marked improvement.

- Moderate improvement: $50 \%$ to $74 \%$ improvement in the Brief Psychiatry Rating scale scoring pattern was recorded as moderate improvement.

- Improvement: $25 \%$ to $49 \%$ improvement in the Brief Psychiatry Rating scale was considered as improvement.

- Unchanged: Less than $25 \%$ reduction in the Brief Psychiatry Rating scale was noted as unchanged.

\section{Observations and Results:}

Total 137 patients were registered for the study of stress management. Distribution of patients were as follows:

Table No: 1

\begin{tabular}{|c|c|c|c|}
\hline Group & Completed & LAMA & Total Registered \\
\hline A & 35 & 06 & 41 \\
\hline B & 38 & 06 & 44 \\
\hline C & 43 & 09 & 52 \\
\hline & 116 & 21 & 137 \\
\hline
\end{tabular}

Total 137 patients were registered for the present study which was divided into 3 groups, total 21 patients left the treatment. 6 patients in Jaladhara group (GP-A), 6patients in Tailadhara group (GP-B) and 9 patients in Mansyadi Kwatha group (GP-C).

Reason may be they could not come daily for Shirodhara and another was they wanted a miraculous result in just one sitting of Shirodhara. Few patients who completed 7 days of Dhara did not complete the medicine course as they felt relieved with only Shirodhara. 


\section{Demographic data:}

Table No: 2

\begin{tabular}{|l|c|}
\hline \multicolumn{1}{|c|}{ Data } & $\%$ \\
\hline Age- 31-45yrs & 41.60 \\
\hline Sex- females & 51.82 \\
\hline Religion- Hindu & 91.24 \\
\hline Living arrangement- with family & 90.51 \\
\hline Education- Graduate & 32.11 \\
\hline Marital status- married & 84.67 \\
\hline Occupation- house wife & 43.06 \\
\hline Socio economic- middle class & 39.41 \\
\hline Family history & 27.73 \\
\hline Diet & 87.59 \\
\hline Lavana rasa more & 75.91 \\
\hline Shamshana & 53.28 \\
\hline Poor quantity of food & 78.83 \\
\hline Poor appetite & 70.80 \\
\hline Urban area of residence & 94.89 \\
\hline Not doing exercise & 87.59 \\
\hline Disturbed sleep & 89.05 \\
\hline Nightmares & 39.41 \\
\hline 5-6 hrs sleep & 85.40 \\
\hline More than 6hrs of working & 67.15 \\
\hline Moderate nature of work & 51.82 \\
\hline Job satisfaction & 54.01 \\
\hline Pallor & 85.40 \\
\hline Nadi pariksha & 71.53 \\
\hline Constipation & 62.77 \\
\hline Normal urine frequency & 90.51 \\
\hline
\end{tabular}

Table No: 3

\begin{tabular}{|l|c|}
\hline \multicolumn{1}{|c|}{ Parameters } & Maximum\% \\
\hline Sharira Prakruti- Vaata- Pitta Prakruti & 72.26 \\
\hline Manas Prakruti- Rajasika Prakruti & 70.80 \\
\hline Sara-Madhyam & 87.59 \\
\hline Samhana-Madhyam & 86.86 \\
\hline Satva-Avara & 54.74 \\
\hline Satmya- Madhyam & 92.70 \\
\hline Pramana-Madhyam & 89.05 \\
\hline Vyayam- Madhyam & 86.13 \\
\hline Desha- Jangama & 93.43 \\
\hline
\end{tabular}

Causative factors: The most common causative factors were change in social activities $83.94 \%$, change in amount of recreation $78.10 \%$, change in job responsibilities $65.68 \%$, personal illness $62.77 \%$, change in eating habits $59.12 \%$ \& change in sleeping habits $58.39 \%$. 
Srotas Dushti wise: Maximum Sroto Dushti is of Rasavaha Srotas found in $97.81 \%$ of patients \& Asthivaha Srotas in $97.08 \%$ of patients followed by Annavaha Srotas Dushti in 95.62.

All the patients i.e. $100 \%$ had chief complaint of can't concentrate, than $97.81 \%$ had can't cope, $95.62 \%$ had always tired, $94.89 \%$ of patient had feel hopeless \& helpless \& trouble sleeping \& $85.40 \%$ had depressed, $89.05 \%$ were uninterested in life in general.

Associated complains were mainly Gabharaman in $53.28 \%$, negative thinking in $49.63 \%$, chest pain in $33.57 \%$ and burning in chest in $37.22 \%$.

Table No: 4 Total effect on brief pshychiatric rating scale in Group-A (jaladhara group):

\begin{tabular}{|l|c|c|c|c|c|c|c|}
\hline \multicolumn{1}{|c|}{ BPS } & $\mathbf{N}$ & mean & $\begin{array}{c}\text { \% of } \\
\text { relief }\end{array}$ & SD & SE & t & P \\
\hline Somatic concern & 29 & 1.45 & 69.16 & 0.74 & 0.14 & 10.41 & $<0.001$ \\
\hline Anxiety & 35 & 2.03 & 69.67 & 0.45 & 0.08 & 26.12 & $<0.001$ \\
\hline $\begin{array}{l}\text { Emotional } \\
\text { withdrawal }\end{array}$ & 34 & 1.74 & 69.23 & 0.62 & 0.11 & 16.12 & $<0.001$ \\
\hline $\begin{array}{l}\text { Conceptual } \\
\text { disoranization }\end{array}$ & 34 & 1.38 & 64.51 & 0.55 & 0.09 & 14.40 & $<0.001$ \\
\hline Guilt feeling & 33 & 1.73 & 69.35 & 0.57 & 0.10 & 17.02 & $<0.001$ \\
\hline Tension & 35 & 2.08 & 71.77 & 0.51 & 0.09 & 23.98 & $<0.001$ \\
\hline $\begin{array}{l}\text { Mannerism } \\
\text { posturing }\end{array}$ & 21 & 0.81 & 57.14 & 0.60 & 0.13 & 6.02 & $<0.001$ \\
\hline Grandiosity & 25 & 1.36 & 72.92 & 0.91 & 0.19 & 7.34 & $<0.001$ \\
\hline Hostility & 30 & 1.80 & 75.95 & 0.81 & 0.15 & 12.03 & $<0.001$ \\
\hline Suspiciousness & 33 & 1.73 & 75.77 & 0.88 & 0.15 & 11.16 & $<0.001$ \\
\hline $\begin{array}{l}\text { Hallucinatory } \\
\text { behaviour }\end{array}$ & 00 & 00 & 00 & 00 & 00 & 00 & 00 \\
\hline Motor retardation & 34 & 1.21 & 70.58 & 0.54 & 0.09 & 12.87 & $<0.001$ \\
\hline Uncooperativeness & 32 & 1.31 & 72.37 & 0.69 & 0.12 & 10.55 & $<0.001$ \\
\hline $\begin{array}{l}\text { Unusual thought } \\
\text { affect }\end{array}$ & 34 & 1.41 & 76.59 & 0.66 & 0.11 & 12.35 & $<0.001$ \\
\hline Excitement & 34 & 1.85 & 80.35 & 0.74 & 0.13 & 14.31 & $<0.001$ \\
\hline Disorientation & 04 & 0.75 & 60 & 0.50 & 0.29 & 2.59 & $<0.001$ \\
\hline Blunted affect & 33 & 1.42 & 72.16 & 0.61 & 0.11 & 13.12 & $<0.001$ \\
\hline pro.01:Highty
\end{tabular}

$\mathrm{p}<0.001$ : Highly significant

Table No: 5 Total effect on brief psychiatric scale In Group -B ( Taildhara Group)

\begin{tabular}{|l|c|c|c|c|c|c|c|}
\hline \multicolumn{1}{|c|}{ BPS } & $\mathbf{N}$ & mean & $\begin{array}{c}\text { \% of } \\
\text { relief }\end{array}$ & SD & SE & T & P \\
\hline Somatic concern & 25 & 1.64 & 78.85 & 0.64 & 0.13 & 12.59 & $<0.001$ \\
\hline Anxiety & 37 & 2.57 & 88.29 & 0.55 & 0.09 & 27.77 & $<0.001$ \\
\hline $\begin{array}{l}\text { Emotional } \\
\text { withdrawal }\end{array}$ & 38 & 2.21 & 85.06 & 0.53 & 0.09 & 25.47 & $<0.001$ \\
\hline $\begin{array}{l}\text { Conceptual } \\
\text { disorganization }\end{array}$ & 38 & 1.53 & 78.68 & 0.56 & 0.09 & 16.67 & $<0.001$ \\
\hline
\end{tabular}




\begin{tabular}{|l|c|c|c|c|c|c|c|}
\hline Guilt feeling & 35 & 1.71 & 85.71 & 0.67 & 0.11 & 14.98 & $<0.001$ \\
\hline Tension & 38 & 2.29 & 80.63 & 0.65 & 0.11 & 21.30 & $<0.001$ \\
\hline $\begin{array}{l}\text { Mannerism } \\
\text { posturing }\end{array}$ & 16 & 0.43 & 44.25 & 0.51 & 0.13 & 3.31 & $<0.001$ \\
\hline Grandiosity & 20 & 1.25 & 69.44 & 0.72 & 0.16 & 7.61 & $<0.001$ \\
\hline Hostility & 35 & 1.97 & 87.68 & 0.71 & 0.12 & 16.27 & $<0.001$ \\
\hline Suspiciousness & 32 & 1.81 & 82.56 & 0.86 & 0.15 & 11.75 & $<0.001$ \\
\hline $\begin{array}{l}\text { Hallucinatory } \\
\text { behaviour }\end{array}$ & 03 & 0.33 & 34 & 0.58 & 0.41 & 0.82 & - \\
\hline Motor retardation & 34 & 1.09 & 77.30 & 0.71 & 0.12 & 8.78 & $<0.001$ \\
\hline Uncooperativeness & 30 & 1.2 & 86.71 & 0.61 & 0.11 & 10.59 & $<0.001$ \\
\hline $\begin{array}{l}\text { Unusual thought } \\
\text { affect }\end{array}$ & 36 & 1.44 & 84.57 & 0.56 & 0.09 & 15.32 & $<0.001$ \\
\hline Excitement & 37 & 1.94 & 85.71 & 0.62 & 0.10 & 18.79 & $<0.001$ \\
\hline Disorientation & 04 & 1.25 & 62.50 & 0.50 & 0.29 & 4.33 & $<0.01$ \\
\hline Blunted affect & 37 & 1.38 & 74.19 & 0.68 & 0.11 & 12.14 & $<0.001$ \\
\hline
\end{tabular}

$\mathrm{p}<0.001$ : Highly significant

Table No: 6 Total effect on brief psychiatric scale in Group -C (only oral drug)

\begin{tabular}{|l|c|c|c|c|c|c|c|}
\hline \multicolumn{1}{|c|}{ BPS } & $\mathbf{N}$ & mean & $\begin{array}{c}\text { \% of } \\
\text { relief }\end{array}$ & SD & SE & T & P \\
\hline Somatic concern & 29 & 1.04 & 60.98 & 0.65 & 0.13 & 8.14 & $<0.001$ \\
\hline Anxiety & 43 & 1.81 & 63.42 & 0.76 & 0.12 & 15.39 & $<0.001$ \\
\hline $\begin{array}{l}\text { Emotional } \\
\text { withdrawal }\end{array}$ & 43 & 1.69 & 65.46 & 0.56 & 0.09 & 19.72 & $<0.001$ \\
\hline $\begin{array}{l}\text { Conceptual } \\
\text { disorganization }\end{array}$ & 43 & 1.07 & 60.97 & 0.55 & 0.09 & 12.56 & $<0.001$ \\
\hline Guilt feeling & 41 & 1.00 & 58.48 & 0.63 & 0.10 & 10.00 & $<0.001$ \\
\hline Tension & 43 & 1.93 & 65.87 & 0.51 & 0.08 & 24.68 & $<0.001$ \\
\hline $\begin{array}{l}\text { Mannerism } \\
\text { posturing }\end{array}$ & 11 & 0.09 & 10 & 0.30 & 0.09 & 0.95 & - \\
\hline Grandiosity & 07 & 0.14 & 12.28 & 0.38 & 0.15 & 0.93 & - \\
\hline Hostility & 39 & 1.08 & 59.34 & 0.58 & 0.09 & 11.45 & $<0.001$ \\
\hline Suspiciousness & 38 & 1.21 & 62.37 & 0.70 & 0.12 & 10.47 & $<0.001$ \\
\hline $\begin{array}{l}\text { Hallucinatory } \\
\text { behaviour }\end{array}$ & 00 & 00 & 00 & 00 & 00 & 00 & - \\
\hline Motor retardation & 33 & 0.52 & 44.07 & 0.51 & 0.08 & 5.74 & $<0.001$ \\
\hline Uncooperativeness & 33 & 0.42 & 38.39 & 0.56 & 0.09 & 4.28 & $<0.001$ \\
\hline $\begin{array}{l}\text { Unusual thought } \\
\text { affect }\end{array}$ & 42 & 0.83 & 53.90 & 0.69 & 0.11 & 7.67 & $<0.001$ \\
\hline Excitement & 43 & 1.44 & 70.59 & 0.73 & 0.11 & 12.74 & $<0.001$ \\
\hline Disorientation & 17 & 0.41 & 47.62 & 0.62 & 0.15 & 2.66 & $<0.01$ \\
\hline Blunted affect & 42 & 1.12 & 62.50 & 0.59 & 0.09 & 12.08 & $<0.001$ \\
\hline p<0.001:Highly
\end{tabular}

$\mathrm{p}<0.001$ : Highly significant 
Effect of therapies on chief complaints :

Table No: 7 Comparative Data Of \% Wise Relief In All The Three Groups:

\begin{tabular}{|l|c|c|c|}
\hline \multicolumn{1}{|c|}{ Chief complaints } & Group- A & Group- B & Group- C \\
\hline Can't cope & 77.82 & 84.29 & 61.62 \\
\hline Can't concentrate & 79.56 & 83.33 & 57.99 \\
\hline Feel hopeless \& helpless & 78.03 & 86.36 & 59.14 \\
\hline Depressed & 82.03 & 88.34 & 74.70 \\
\hline Always tired & 67.01 & 86.60 & 82.27 \\
\hline Often irritable \& angry & 80.35 & 83.45 & 75.66 \\
\hline Eat too much & 33.33 & 50 & 66.67 \\
\hline Eat too little & 85.10 & 86.70 & 75.69 \\
\hline Trouble sleeping & 69.71 & 96.23 & 47.57 \\
\hline Frequent headache & 96.94 & 97.23 & 55.68 \\
\hline Frequent backache & 65.73 & 72.68 & 62.98 \\
\hline Frequent pain in legs & 73.68 & 75 & 62.50 \\
\hline No time to talk to friends \& family & 69.12 & 63.64 & 70 \\
\hline Not interested in sex & 55.33 & 85.71 & 57.80 \\
\hline Always sick get cough \& cold \& other viral infection & 100 & 66.67 & 84.72 \\
\hline Allergies & 24.81 & 00 & 40 \\
\hline Skin rashes & 69.35 & 54.55 & 50.22 \\
\hline IBS & 85.71 & 100 & 78.57 \\
\hline Hyper gastritis & 100 & 100 & 93.41 \\
\hline Constipation & 100 & 100 & 91.51 \\
\hline Not interested in life in general & 74.07 & 80.09 & 64.62 \\
\hline
\end{tabular}

Table no: 8 Assessment of Shirodhara:

\begin{tabular}{|l|c|c|c|c|}
\hline $\begin{array}{l}\text { Samayaka Shirodhara Lakshana(Symptoms of properly } \\
\text { performed Shirodhara) }\end{array}$ & $\begin{array}{c}\text { Group- } \\
\text { A }\end{array}$ & $\%$ & $\begin{array}{c}\text { Group- } \\
\text { B }\end{array}$ & $\%$ \\
\hline Sthairya Vaaga (Stability of speech) & 24 & 68.51 & 14 & 36.84 \\
\hline $\begin{array}{l}\text { Sthairya Mana } \\
\text { (Stability of Mind) }\end{array}$ & 35 & 100 & 35 & 92.1 \\
\hline $\begin{array}{l}\text { Sthairya Sharirabala } \\
\text { (Enhances the physical stamina) }\end{array}$ & 34 & 97.14 & 36 & 94.73 \\
\hline Ahara Akanksha (Promotes appetite) & 29 & 82.85 & 35 & 92.1 \\
\hline Dhriti (Promotes intellect) & 35 & 100 & 34 & 89.47 \\
\hline Vaani Madhura (Promotes sweetness of voice) & 29 & 82.85 & 23 & 60.52 \\
\hline Netra Prakasho Agadaha (Improves the eye sight) & 34 & 97.14 & 36 & 94.73 \\
\hline Tvacha Mruduta (Promotes smoothness of skin) & 12 & 34.28 & 07 & 18.42 \\
\hline $\begin{array}{l}\text { Shukra Asrigapariposhanam (Nourishes the body } \\
\text { tissues) }\end{array}$ & 33 & 94.28 & 36 & 94.73 \\
\hline Rat Rati (Promotes sexual function) & 07 & 20 & 10 & 26.31 \\
\hline $\begin{array}{l}\text { Alpa Ushana } \\
\text { (Decrases the body temperature) }\end{array}$ & 12 & 34.28 & 06 & 15.78 \\
\hline
\end{tabular}

In Jaladhara group Dhriti and Sthairya Mana is obtained in 100\%. And Sthairya Sharira Bala and Netra Prakasho Agadaha is obtained in $97.14 \%$

In Tailadhara group 94.73 \% of patient had Sthairya Sharira Bala, Netra Prakasho Agadaha Shukra Asrigapariposhanam, and $92.10 \%$ of patient had Sthairya Mana, Ahara Akanksha. 
Table No 9 : Total effect of therapy in recurrence:

\begin{tabular}{|l|l|l|l|l|l|l|}
\hline Recurrence & Gp A & \% & Gp B & \% & Gp C & \% \\
\hline Present & 05 & 14.29 & 01 & 2.63 & 09 & 20.93 \\
\hline Absent & 30 & 85.71 & 37 & 97.37 & 34 & 79.07 \\
\hline
\end{tabular}

Recurrence was obtained in $14.29 \%$ of patient in Jaladhara group, and $20.93 \%$ in Mansyadi Kwatha Group. While only 2. $63 \%$ of recurrence is obtained in Tailadhara group

\section{Discussion:}

Effect on brief psychiatric rating scale: It was observed that symptoms like Somatic concern, anxiety, emotional withdrawal, Guilt feeling, Tension etc occur due to change in normal functions of various parts of brain and specially hypothalamus. On observing the relief obtained in brief psychiatric rating scale through Shirodhara the following possible explanation can be given.

\section{Effect on central nervous system:}

The hypothalamus controls many body activities and is one of the major regulators of homeostasis. Sensory input from the external and internal environments ultimately comes to the hypothalamus via sensory pathways originating in somatic and visceral sense organs. Impulses from sound, taste, and smell receptors all reach the hypothalamus. Other receptors within the hypothalamus itself continuously monitor osmotic pressure, certain hormone concentrations, and the temperature of blood.

1) Control of autonomic nervous system: Most regulation of involuntary activities of smooth muscles, cardiac muscles and glands by the autonomic nervous system originates in the brain stem and nearby brain region called the hypothalamus.

2) control of pituitary gland: The hypothalamus produces several hormones and has two types of important connections with the pituitary gland.

3) Regulation of emotional and behavioural patterns: Together with the limbic system with the hypothalamus regulates feelings of rage, aggression, pain, and pleasure and behavioural patterns of sexual arousal.

4) Regulation of eating and drinking.

5) Control of body temperature.

6) Regulation of diurnal (daily) rhythms and states of consciousness.

Signals from the hypothalamus and even from the cerebrum can affect the activities of almost all the brain stem autonomic control centers. $(8,9)$ Control of Corticotrophin Releasing Hormone (CRH) is also from hypothalamus. Serotonin or 5Hydroxytryptophan (5 HT) is concentrated in the neurons in a part of the brain stem called the raphe nucleus. Axon projecting from the raphe nucleus terminates in the hypothalamus and other part of the brain and spinal cord. Serotonin is thought to be involved in inducing sleep, sensory perception, temperature regulation, and control of mood. More serotonin available in the synaptic cleft may allow signals to pass from one neuron to another more easily. Various other nucleus of limbic system like amygdaloid, thalamus and Locus Ceruleus are all involved with the psychic behavior of an individual. It can be ultimately postulated that Shirodhara may be having some effect on hypothalamus resulting in the effect of brief sychiatric rating scale.

\section{Mode of action of shirodhara:}

Mode of action of Shirodhara can be studied in following ways:

1. Drug Absorption

2. Physical Effect 
3. Effect on Blood Supply

4. Effect on Marma

1. Drug Absorption: Vaghbhatta has given 4 varieties of Murdha Tail 1) Shiro Abhayanga, 2) Pariseka, 3) Shiro Pichu, and 4) Shiro Basti. Regarding its beneficial effect Vaghbhatta has clearly specified it as "UTTAROTTAR GUNAPRADA" (i.e. sequentially beneficial). This indicates that there are chances of drug absorption from the scalp region otherwise there was no need for these four separate procedure on the head region.

2. Physical effect: The symptoms like tension headache, and muscular tension caused due to sustained contraction of skeletal muscles can be relieved by the physical effect of Shirodhara.

3. Effect on Blood Supply: Shirodhara improves the circulation there by correcting the brain circulation which is very important in stress. Symptom like migraine headache, which is caused by extra cranial Vasodilatation and that the neurological symptoms which are produced by intra cranial vasoconstriction.(10) Shirodhara may be helpful in regularizing the blood supply of brain and can relieve the pain of migraine.

4. Effect on Marma (Vital sites): Out of 37 Marmas in the supraclavicular region, 23 are situated in the head. Shirodhara procedure mainly effects on Sthapani, Shankaha, Utkshepa and Adhipati Marma, which are located in head region.

\section{Total effect of therapy:}

- Marked improvement was obtained in $51.43 \%$ in Gp. A, \& $40 \%$ had moderate improvement.
- In Gp. B $65.79 \%$ had marked improvement while moderate improvement was obtained in $26.32 \%$.

- In Gp. C marked improvement was obtained in $32.56 \%$ \& $41.86 \%$ of patients had moderate improvement. As Taila is considered to be best Vaata Shamaka we can get better result in Tailadhara group.

\section{Mode of action of drug:}

Shirodhara: As per the principle of drug absorption maximum absorption is in the scalp region and comparatively oil is better absorbed than water. Due to tikshana, vyavayi \& sukshma property of til tail it penetrates easily into manovaha srotas correcting vitiation of manas dosha ( Raja \& Tama). At the same bhrimhana, balya, vaata shamana, medhya properties of til tail it corrects all maanas vikaras (Mental Diseases).

Mansyadi kwatha: Bhutaghna prabhava ( Specific effect on micro organisims) of jatamansi \& maadak prabhava (which calms the mind) of khurasini ajwoin corrects the vitiation of maanas dosha ( Raja \& Tama)by penetrating into manovaha srotas. Medhya ( promotes the intellect) \& nidrajana (the one which induces sleep) property of jatamansi \& rasayana (Rejuvination) \& balya ( promotes the physical and mental strength) property of ashwagandha corrects all maanas vikara. Tridosha shamaka (subsides the increased bio humors) property of jatamansi \& kapha vaata shamaka property of ashwagandha corrects all the somatic ailments.

\section{Conclusion:}

- Main causative factor as per Ayurveda is Pragnapradha \& main Manas Dosha involved is Raja. Sharirika 
Dosha are mainly: Vaata - Prana, Udana \& Vyana, Pitta - Sadhaka, Dushaya- Mana and all Dhatus. Rasavaha, Raktavaha, Asthivaha and Swedavaha are main Srotas involved in the disease stress.

- For any disease occurring in head region Vaata is main Dosha as it is controller of mind. For Vaata Shamana oil is considered to be best. So various Snehana treatment under the topic of "Murdha Tail" is described, where Shirodhara is included under "Pariseka"(Seka). Shirodhara is a part of Snehana Kalpana (Bahya Snehana).

- Due to specific procedure of Shirodhara i.e. pouring of liquid media on forehead, patient's concentration is increased \& hence his mind is relaxed from negative thoughts. This is the procedural effect, which is equally obtained in Jaladhara \& Tailadhara.

- Due to Vaata Shamaka and Medhya properties of Tila Tail it provided better relief in sign \& symptoms of stress.

- Tailadhara provided better relief in most of the chief complaints and in Brief psychiatric Rating Scale compared to Jaladhara.

\section{References:}

1. Gala's Desk Dictionary,EnglishEnglish -Hindi \& Hindi-Hindi-English combined Dictionary, compilers L.R. Gala, B.L.Shah \& L.B.Gokani. Gala publishers Ahmedabad. Page no 385.

2. Ashtanga Hridaya, Vidyotini hindi commentary by Atridev Gupta, 11th edition, Chaukhambha Sanskrit Sansthana,1993 Varanasi Sutra Sthana 11/1 page no 85 .

3. Charaka Samhita, Vidyotini hindi commentary by K.N. Shashtri and G.
N. Chaturvedi.18th edition Chaukhambha Bharti Academy,1992 Varanasi, Sutra Sthana 12/8 page no 246.

4. Ashtanga Samgraha, with Arthaprakashika commentary by Vaidya Shree Govardhana Sharma Changani, 14th edition Chaukhambha Sanskrit Sansthana 2003 Varanasi, Sutra Sthana 20/2-.3 page no.188 \& 189.

5. Ashtanga Hridaya, Vidyotini hindi commentary by Atridev Gupta, 11th edition, Chaukhambha Sanskrit Sansthana,1993 Varanasi Sutra Sthana 12/4-5 page no 90.

6. Ashtanga Hridaya, Vidyotini hindi commentary by Atridev Gupta, 11th edition, Chaukhambha Sanskrit Sansthana, 1993 Varanasi Sutra Sthana 12/13 page no 91.

7. Charaka Samhita, Vidyotini hindi commentary by K.N. Shashtri and G. N. Chaturvedi . 18th edition Chaukhambha Bharti Academy,1992 Varanasi, Sutra Sthana 5/81-83 page no 127-128.

8. Gerard j. Tortora \& Sandra GrabowskiPrinciples of Anatomy \& Physiology, 8th edi; Haper Collins college publication, 1996. Chapter 14 page no 406.

9. Arthur C. Guyton \& John E. HallTextbook of medical physiology, 9th edition, Prism books pvt Ltd, Banglore, 1996. Chapter 58 page no 752.

10. Harrison's- Principles of internal medicine, 14th Edition. International edition. Part 14,Section 2- Diseases of the Central Nervous System, Chapter 364 page no 2308 . 